\title{
«The» or «A» leading organization in migration? IOM as an actor in global migration governance
}

Stefan Rother*

\begin{abstract}
The emerging global governance of migration is characterized by its fragmentation in terms of institutions, underlying norms and conventions. The International Organization for Migration (IOM) holds a peculiar place within this framework: On the one side, it has been situated outside the United Nations System until very recently, considers itself a «non-normative» agency, and has mostly acted as a profit-based service provider for nation-states. On the other side, the IOM has been instrumental in establishing influential norms such as "migration management», it has been lauded "a leading agency on migration» by the UN and its member states, and moved closer to the UN system as a «related organization» in September 2016. However, the opposition to the original suggestion of calling the IOM "the leading agency on migration» highlights - beyond mere semantics - that the role of the organization is still nor clearly defined and remains contested. This contribution analyses the actorness IOM has achieved in global migration governance.
\end{abstract}

Keywords: global migration governance, development, IOM, actorness, international organizations.

* German. Institut Arnold Bergstraesser, University of Friburgo, Germany. E-mail: mail@stefan-rother.de 


\section{Intro}

When the second United Nations High-level Dialogue (UN-HLD) on International Migration and Development: «Making Migration Work» took place October 3-4, 2013 in New York, a running commentary on the social media platform Twitter was still a relatively new phenomenon. But while, for example, the International Labor Organisation (ILO) was almost completely absent on the social media platform, the New York and Geneva offices of the International Organisation for Migration (IOM) were sending out Tweet after Tweet:

(IOM Director General William Lacy) Swing: «As global lead agency on migration, IOM puts the protection of \# migrants in all that it does».

\#Chile at \#HLD2013: «IOM has played an important role as IGO and in preparing for the High-level Dialogue \#migration».

\#Austria: «Would like to thank \#IOM for its contribution to the \#HLD2013». IOM is uniquely placed to enrich this debate in years to come» (all IOM tweets from October 3).

Nepal: «@IOM_news can play important role in enhancing positive impact of \# migrants».

Uruguay at \#HLD2013: «Plenary notes IOM as the lead global migration organization».

«\#Egypt at \#HLD2013 asks to explore ways of strengthening involvement of IOM given its standing as leading IGO in the field of migration» and «is proud hosting its regional office for \#MENA»

@UNAOC: «Importantworkwith @IOM_news on creating \#bestpractices for \#migration» (all IOM tweets from October 4).

These quotes - which are just a small selection of many others in a similar vein and fairly representative of the public image projected by IOM in the past years - can be read in a number of ways. On the one hand, we get the picture of an organisation aching for acknowledgement, collecting every bit of praise it can get hold of. On the other hand, there is clearly a solid foundation for this selfpromotion, since a diverse number of states, including countries of origin and destination came forward to stress the important role of IOM. They were joined by an initiative based within the UN system, UNAOC (United Nations Alliance 
of Civilizations), and during the October 4 session a major regional organisation issued praise as well: A representative stressed that the European Union (EU) "appreciates the leading role of IOM in international migration and development». Such statements give the impression that the speakers do not see IOM as a mere tool they can use to further their purposes, but as an actor in its own right that plays a significant role and shows leadership.

This level of actorness is at the heart of this paper ${ }^{1}$. As Pécoud rightly points out, IOM has until very recently remained largely under-researched; this holds even more true for theoretical approaches and « virtually no study looks at IOM from an IR perspective» (Pécoud 2018, p. 1623). For example, in Alexander Betts edited volume on global migration governance, several contributions mention IOM but mostly descriptive and rather in passing (Betts 2011a). The organisation receives more attention in the introduction and conclusion which employ a specific IR perspective, but it is granted very limited actorness: For Betts, IOM «exists mainly as a service provider to states, working on specific projects according to the demands and priorities of donor states», its approach is in many ways "nearer to a private firm than a typical international organizations» and it «has very little normative vision of its own» (Betts 2011b, p. 13).

I argue that, while these characterizations cover important facets of IOM, we can get a fuller picture of the organisation by looking at its role in the multiple layers of the emerging global migration governance. To this regard, in a first section I will discuss the literature on the agency of international organisations. This is followed by an analysis of the strategies employed by IOM towards multiple actors and in fora such as the UN-HLD, the Global Forum on Migration and Development (GFMD) and the deliberations on the global compact for safe, orderly and regular migration. In the conclusion I will discuss further fields of study.

The findings are based on comprehensive document analysis, interviews and participant observation in global fora such as the Global Forum on Migration and Development (GFMD - all meetings since 2008), the UN High-Level Dialogue on Migration and Development (UN-HLD 2013) and the «migration week» 2018 in Marrakesh, including the Intergovernmental Conference on the Global Compact for Migration.

${ }^{1}$ Earlier versions of this paper were presented at the conference «Managing Migration in World Society. International Organizations in Migration Politics II», Carleton University, Ottawa, in March 2017 and at the ECPR General Conference. Wroclaw, Poland, in September 2019. I thank all participants and discussant for their feedback. 


\section{International Organisations as Actors}

Recent developments in international politics may lead to the perception that international organizations are challenged institutions, if not to say that their authority is in decline: This ranges from the Visegrád Group countries in the EU refusing to accept decisions of the regional organisation to the more drastic Brexit decision and up to the Trump administration distancing itself from the World Trade organisation (WTO), the UN and pretty much every form of multilateral agreements and international organisations. But, as a recent study found « international organisations have become more authoritative over the past few decades - that is, they are now less dependent on control by individual members» (Lenz 2017, p. 1; Hooghe et al. 2017). As an indicator for this development, the researchers see the increasing extent in which states resort to either pooling (endorsing majoritarian forms of decision making) or delegation (empowering independent institutions to act on their behalf); typical for task-specific organisations in the study, IOM ranks medium on delegation and high on pooling (ibid.) The reasons for the rise in international authority are seen in the functional quest for effective cooperation, non-governmental actors increasingly demanding political participation and «the diffusion of authoritative institutional templates amongst international organisations» (Lenz 2017, p. 1).

This comprehensive empirical study contributes to what can be considered an organizational turn in International relations (IR) Theory (Ellis 2010). While in organisational theory, the inherent agency and autonomy of international organisations are largely uncontested, there is more controversy in the still dominantly state-centric field of IR theory. Ellis sees «an intellectual inconsistency in International Relations (IR) scholarship that views states, but not IOs, as unitary actors when both are, in fact, corporate entities» (Ellis 2010, p. 12). In other words, the insights from research on states as actors in the international system should be applied to international institutions as well. In his classic book "Man, the State and War», Kenneth Waltz introduced three images of analysis which could explain the origins of conflict in the international system (Waltz 2001). The First Image examines the role of leaders, the second the internal structure and conflict of states and the third (more fully developed in his later works) the international system.

Based on Baum and Rowleys hierarchy of levels of organisations (Baum and Rowley 2007), Ellis suggest that these images could be used for corresponding 
levels of analysis for international organisations: The first image would correspond to intraorganizational analysis and look at the role of secretariats, councils or epistemic communities (however, I would argue that the last one does not always fit neatly into the internal dimension since there are likely links to the "Outside world»). The second image can correspond to the organizational analysis and range from intra-system bargaining to funding patterns, voting rules and the interaction of IOs with states and non-governmental organisations (NGO). The third image finds its equivalent in interorganizational analysis which can focus on the structure of the international system, networks of IOs with other IOs or NGO and the role of norms or change agents. An analysis cutting across levels can be the dimension of institutional learning which relates to the diffusion of successful templates mentioned above.

The growing interest in international organisations has manifested itself in several publications, among them the probably most comprehensive books series "Global Institutions". After the finalization of this manuscript, a dedicated monograph on the IOM has been published (Bradley 2020). Before that, tellingly, besides an edited volume on the migration industry (Gammeltoft-Hansen and Sørensen 2013), the only migration-related institution that had receiver significant attention in the series was the United Nations High Commissioner for Refugees (UNHCR) in a monograph (Deardorff Miller 2017) and in a book chapter in Joel Oestreichs edited volume International organizations as self-directed actors (Oestreich 2012a). The latter volume provides a framework for analysis that seems particularly suited for IOM.

Oestreich responds to the mainstream approaches in IR theory that assume that it is the states that act, working through the IOs they create; these assumptions are made by «traditional Realists, who see IOs as essentially meaningless bodies in a world of state actors, and also by many branches of Liberal theory, which assume that IOs influence world politics as loci of social norms and expectations, but not as agents with their own wants and desires, and the ability to act on them» (Oestreich 2012b, p. 1). Constructivist, on the other hand, look at the creation and diffusion of norms in the international system; these norms might not just float around but also manifest themselves in a more concrete form - international organisations.

The ontological position of Oestreich and his co-authors is «that IOs exist independently of states, and have an effect of their own that makes them matter in various ways» (Oestreich 2012b, p. 5). One way to analyse international 
organisations as actors is principal-agent-theory, with international organisations being hired hands, serving the interests of states who delegate tasks they cannot or want not perform themselves (Hawkins et al. 2006). Even if the international organisations are "servants» in this scenario, they are actors, nonetheless, dealing with issues on behalf of others. In addition, over the course of time servants may well develop their own minds and have their own interests in sight. These interests may not necessarily be fully aligned with the principals, in particular when there is «slack» in oversight: «Principal-agent theory and work on bureaucratic behavior suggests that the primary goal of bureaucracies is their own expansion: expansion of budgets, of powers, and of existence over time» (Oestreich 2012b, p. 7; Brehm and Gates 2002). This tendency is amply illustrated on multiple levels, from national government departments up to the turf wars of international organisations in general and UN agencies in particular. Organisations can increase their «slack» if they can use asymmetric information - for example, their expert knowledge - to their advantage and if their principals are large in number and/or have no unified interests among themselves (Oestreich 2012 b, p. 7). Seeing international organisations as corporate entities, as suggested above, would focus the analysis also on the internal structure of the organisations, the interests of the people working there, its branches and leaders.

When applying a constructivist lens to principal-agency theory, one can detect indicators of the relationship between states and international organisations becoming more equal. International organisations can use their control over bureaucratic power and resources to influence state behaviour and states can «then find themselves engaged in an intersubjective relationship with these IOs and inevitably find their own interests affected by this relationship, as their own identity shifts». (Oestreich 2012b, p. 8). The power, influence and to a degree independence if not autonomy of international organisations hence stem mostly from ideas, knowledge and, discourses. The organisations are not just executing orders in a bureaucratic manner but can also «serve as conduits for globalized or globalizing ideas; they pick up, internalize, and disseminate ideas that are part of their operating environment, when those ideas seem to match with the mandate of the bureaucracy» (Oestreich 2012b, p. 9). This is a fluid process where the international environment and other actors such as epistemic communities can play their part in shaping these ideas. Therefore, international organisations cannot be analysed sufficiently in isolation, but one has to take into consideration the network(s) they are part of. 


\section{Researching IOM as an actor in international relations}

How can these theoretical approaches contribute to research on IOM as an actor? The approach with probably the highest potential is at the same time one of the most challenging: Trying to take a systematic look inside the «black box» of the international organisation. IOM is notoriously secretive when it comes to its internal workings, as has been attested in conversations by the author with several researchers trying to approach the organisation with request for information about its handlings of cases, finances etc. Nevertheless, an organisational ethnography could be particularly useful. For once, conducting an analysis based on the levels of organisation - or «images» - could shine light on the complex internal dynamics of the organisation, which has on the one hand a strong centre with its headquarter in Geneva and representation at the UN, but on the other hand carries out much of its work "on the ground» with a plethora of national, sub-national and regional offices and programs plus administrative centres, special liaison offices, as well as an African Capacity building (ACBC) and a Global Migration Data Analysis Centre (GMDAC).

There has been imported work done on the role of IOM working with countries of origin, transit and destination (Geiger 2018; Barber and Bryan 2018; Fine 2018; Dini 2018); now, a next step would be to situate these findings within a larger analysis of the interplay between intraorganizational, organizational and interorganizational levels. How are IOM principals adhered to on the ground, how do the outcomes - positive or negative - of such projects affect the overall strategy of the organisation? What is the effect of civil society critique on programs that actually violate the human rights of migrants (Andrijasevic and Walters 2010, p. 980)?

A common theme of the literature on the actorness of international organisations is the importance of the people who work within them. Hence, to fully comprehend the actions of IOM it is important to include the role of the Director General, who has traditionally been former U.S. Diplomat. After being an U.S. ambassador, the previous DG William Lacy Swing served also in several functions within the United Nations, which very likely had an effect on the negotiations of bringing the organisation closer to the UN system. As an indicator of changes in the international setting, when it came to selecting his successor, no majority was found for the controversial US candidate; instead, the Portuguese politician António Manuel de Carvalho Ferreira Vitorino, a former European 
Commissioner for Justice and Home Affairs, was selected in June 2018 and serves currently as DG. The tentative initial impression after his first two year in office is a willingness to open up the organisation to discourses with more stakeholders, in particular civil society, and an openness for further involvement with the UN system.

Such an analysis should not stop at the top, though, but should also take into account the people on the ground. Here, IOM seems to be far from a uniform entity, with diverse project groups, a high fluctuation of staff in some offices and the subcontracting of experts for project implementation. This analysis could disturb the perceived dichotomy, not uncommonly held among civil society and critical researchers, of which is the "good» and which is the "bad» international organisation when it comes to migration; as one of my respondents quipped on this matter: «IILO is a well-intentioned organisation where some questionable people work; IOM is a questionable organisation where several well-intentioned people work». (informal exchange during the GMD in Dhaka, Bangladesh, 10 December 2016).

Obviously, such a comprehensive analysis is easy to call for and hard to implement, and hence remains a rather long-term goal ${ }^{2}$. Deeper analysis of the «external relations» of the organisation can be seen as a step towards it, though, and to this end the following section will focus on the interorganizational / international level and IOMs quest to achieve agency.

\section{The IOM in global migration governance}

Friends of diplomatic fine print will certainly enjoy paragraph 49 of the New York Declaration for Refugees and Migrants:

We commit to strengthening global governance of migration. We therefore warmly support and welcome the agreement to bring the International Organization for Migration, an organization regarded by its Member States as the global lead agency on migration, into a closer legal and working relationship with the United Nations as a related organization (emphasize added) (United Nations General Assembly 2016, p. 715). 
Obviously, this paragraph sidesteps how the UN General Assembly regards IOM by referring to the self-image of the organisation as supported by its member states. Likewise, in the cooperation agreement concerning the relationship between the UN and IOM it is stated in article 2, Principles: "The United Nations recognizes the International Organization for Migration as an organization with a global leading role in the field of migration».

As one observer of the negotiation process reported: «Due to objections from other agencies, the agreement did not designate IOM as sthe global leading agency on migration», but as having a sleading role».. (email conversation 27 July 2016; for a further source see Weiss and Micinski 2016, p. 3).

This may seem like mere semantics at first, but considering that 28 different components of the UN system deal with migration (Weiss and Micinski 2016, p. 2), being assigned «a» or «the» leading role has potentially far-reaching consequences regarding authority, responsibility and of course prestige. It can also be seen in line with the above discussed tendency of bureaucracies to continuously expand their power and existence. Initially, gaining the rarely used status of a related agency did not actually change that much in practice; it basically extended the previous IOM-UN relationship: «While IOM will now enjoy a seat at the high table of UN policy making, it was hardly lacking influence earlier - particularly in coordination mechanisms, regional task forces, and joint response plans». (Weiss and Micinski 2016, p. 3).

Nevertheless, IOM capitalized on the potential increase in prestige through the new agreement; dropping the «related" part on the way, it now almost obsessively refers to itself in all its press releases and statements as «IOM, the UN Migration Agency", and added the description to its logo. This can be seen as a continuation of the thirst for acknowledgement highlighted by the tweets cited at the beginning of this chapter - and, consequently, on Twitter the handle (i. e. username) of the "Official account of \#IOM, the UN Migration Agency" has been swiftly changed to@UNmigration.

While this approach may seem borderline-preposterous, it can also be considered a major waypoint in IOMs quest for actorness. As has been shown by Pecoud (Pécoud 2018), the history of IOM is one of repeated metamorphosis, with several changes of names and mandates before the organisation reached its current form, the formation for it being established in 1989. The end of the Cold War also marks IOMs transition from a service provider to an agent and on to an organisation with increased independence beyond the principal-agent relationship. Almost from the 
beginning, this process was marked by closer cooperation with the UN: In 1992, IOM became a permanent observer in the General Assembly. This was followed by a formal cooperation agreement in 1996 and a memorandum of understanding (MOU) in 2013, paving the way for the current status as a related agency.

Obviously, the core of IOM until today remains its project-based work, since that is where the overwhelming part of its financing is coming from. But that does not mean that there is a tension between projectization and the aim to count as a recognized actor in global governance: On the contrary, besides being, for bureaucracies, a goal in itself, global prestige is also "good for business» and can lead to the acquisition of more projects in the sinterlocking markets» which international organisations are trying to establish themselves (Ellis 2010, p. 25).

Looking at IOMs policies and activities in the past 20 years, there appear to be a number of strategies directed towards multiple stakeholders with the goal to further its agency. In line with constructivist perspectives, I focus on the ideas and discourses behind these approaches. The main stakeholders are states, the regional level, the public including media and academia, other international organisations and the global governance environment, as well as, lately, migrant civil society.

Strategies towards states and regional organisations and the role of knowledge

Although the new status of the IOM stresses its «non-normative nature», one can actually identify several norms and paradigms of the organisation. The main one is far from a hidden agenda, since it is proclaimed right in the slogan of the organisation: "Managing Migration for the Benefit of All». This paradigm and its actual beneficiaries have been questioned and criticized in research (Geiger and Pécoud 2010; Ashutosh and Mountz 2011; Wise 2018) and among activists, but that has not lessened its appeal to states. It claims that migration can be dealt with in a technocratic, top-down manner by states and international institutions; it also ascribes to migrants the role of sobjects of these management efforts and denies them agency (Piper and Rother 2012, p. 1737) - after all, IOM is an organisation "for migration», not (primarily) «for migrants» and a rightsbased approach to migration is not at the forefront of their agenda. 
The major appeal of the migration management norm or paradigm to states lies in the emphasise of the primacy of states, the notion of territoriality and the upholding of the Westphalian order. Thus, when states - and regional organisations such as the EU - continuously praise IOM, they not only pledge support for the organisation but also for the state-led conceptualisation of migration governance it stands for (and thus, in a way for themselves). One could take this as an indicator for the organisation being merely a vessel to transport states interests, but I would argue that this paradigm has taken on a life of its own beyond the principal-agent relationship.

In addition, there is an increasing dependency of states on the IOM because of its production of hegemonic knowledge; Korneev calls this a strategy of selflegitimization by being seen as the sole source of authoritative knowledge (Korneev 2018, p. 1686). This relates well to the above-mentioned strategy of international organisations using asymmetric information to their advantage and gain more «slack». Besides the expertise gathered in the course of numerous projects, the IOM Global Migration Data Analysis Centre (GMDAC) has been established in 2015 in Berlin as a further source of this knowledge. Actually, the call for «better migration data" has in recent years almost become a mantra in the vein of the migration-development debate; likewise, the assumed link between better data and better migration policies is contested, since the latter is more often based on perceived public opinion, hope for electoral gains, ideologies etc.

As Scheel and Ustek-Spilda (Scheel and Ustek-Spilda 2019) have pointed out, the emphasis on (quantitative) data is very much in line with the migration management strategy of IOM: It « allows agencies like the IOM to present themselves as competent actors with the expertise to deliver projects of migration management» and the way the knowledge is represented enact "migration as a single, coherent and therefore knowable and manageable reality, thus reproducing one of the very doxa of the field of migration management» (Scheel and UstekSpilda 2019, p. 665). In an examination of IOMs Displacement Tracking Matrix (DTM), Cohen and Llewellyn criticize the apolitical nature of the data presentation, where " the subjectivities and agencies of those categorised are erased while being rendered as objects of global control» and conclude that «in its struggle to become the repistemic authority in regards to the production of knowledge about migration the IOM may be overlooking crucial ethical and political considerations in regards to the production of migration data» [emphasize in original) (Cohen and Llewellyn 2019). 
This knowledge is not shared exclusively with the countries who finance the organisations' projects, i.e. predominantly countries of destination; it is also the foundation for support or training in countries of origin. Furthermore, IOM has been very active in the creation and organisation of Regional Consultative Processes (RCPs) - mostly informal, non-binding meetings where the first stage usually focuses on agenda setting and issue definition (Hansen 2010, 9). This provides an additional platform for IOM to promote its management approach. During the GFMD in Ecuador (January 21), the incoming chair UAE organized a side event on January 21, 2020: "GFMD in 2020: Engaging Regional Consultative Mechanisms and GFMD Stakeholder Groups in the Launch of Partnerships ${ }^{4}$. Here, with an IOM representative part of the panel, the IOM-led RCPs were presented as the fora best-suited for the consultations leading up the summit scheduled for January 2021 in Dubai. Again, this approach is open to debate, since for example for Southeast Asia the Bali Process was chosen as the appropriate RCP - notwithstanding the fact, that the focus of this process is not on development but rather on «People Smuggling, Trafficking in Persons and Related Transnational Crime $»^{5}$. The ASEAN Forum on Migrant Labour (AFML) might have been a better fit thematically (Rother 2018) - however, the main external force behind it is the ILO; this thus can be seen as a case of institutional interests taking precedence over content-related considerations.

\section{Public outreach}

Despite - or maybe: because of - its reluctance to public scrutiny, IOM has been increasingly active in the global public sphere. As shown in the beginning, earlier than other organisations IOM has realised the importance of social media. William L. Swing had become a public figure with much more visibility than heads of organisations such as ILO or UNHCR. In speeches, panel discussions and interviews he spoke out against xenophobia and for the protection of migrants and delivered his mantra that «"Migration is not an issue to be solved, but a human reality to be managed ${ }^{6}$. There is now a «Global Migration Film Festival» and one of the largest campaigns of the organisation is called "I am a migrant» - a "platform to promote diversity and inclusion of migrants in society. It's specifi-

${ }^{4}$ See also https://www.gfmd.org/files/documents/se_uae.pdf

${ }^{5}$ https://www.baliprocess.net/

${ }^{6}$ https://www.iom.int/news/migration-world-disarray-iom-director-general 
cally designed to support volunteer groups, local authorities, companies, associations, groups, indeed, anyone of goodwill who is concerned about the hostile public discourse against migrants». However, as de Jong and Dannecker argue, this campaign «is not antithetical to the mission of the IOM to manage migration according to a logic of productivity and rationality, but rather a logical extension of it». (Jong and Dannecker 2017, p. 75)

Knowledge production is also part of this outreach, and IOM is the source of numerous reports geared towards practitioners and academia who use them as a valuable source, although they tend to contribute to depoliticising the issue of migration: As Pécoud has argued, this strategy is achieved through the reliance on ambiguous terms, the development of arguments on an abstract level while avoiding taking clear positions, the technocratic reliance on expertise and the unchallenged «naturalisation of the global socioeconomic and political context in which migration takes place» (Pécoud 2015, p. 95). IOM is further connected to the epistemic community on migration by commissioning reports from its members or inviting them as speakers, for example in its annual Prague summer school on migration ${ }^{8}$. It is also not uncommon for IOM staff members to write about their own organisation in edited volumes (see for example Potaux 2011). A recent attempt to court the research community has been the establishment of the, somewhat pompously titled, «Migration research Leader Syndicate» in support of the 2018 Global compact on safe, orderly and regular migration (GCM). In a first step, Syndicate members were asked to provide their stop three reads, which, not all that unexpectedly, often turned out to be their own writings. Technical papers were commissioned and presented at a workshop in Geneva which focused on two main aspects «i) articulating the conundrums that currently exist on the management of international migration; ii) suggesting how those conundrums might be better reconciled in practical, sustainable ways» (McAuliffe and Klein Solomon 2017a, p. 3). This strong management- and practical-policy-focus notwithstanding, besides issues such as «supporting sedentary communities» and «countering» smuggling», there was also some focus on migrant workers' rights and how they can be strengthened - albeit "without reducing access to other countries' labour markets» (McAuliffe and Klein Solomon 2017a, p. 3). After the publication of these various papers (McAuliffe and Klein Solomon 
2017b), the initiative seems to have become inactive with the adoption of the GCM in December 2018.

$I O M$ as an actor in global migration governance

In line with the tendency of international organisations to expand, IOM has broadened its portfolio in order to include topics that have become en vogue in the past two decades, among them the assumed migration and development nexus (Castles and Wise 2008), climate change and migration and global migration governance in general. The migration-development discourse suits IOM in particular, since it provides the opportunity to focus on the positive aspects of migration and success stories without having to engage with rights-based discourses (Piper and Rother 2014). Likewise, the forum that has emerged as a result of the migration-development «mantra» with its, at least initially, strong focus on remittances (Kapur 2003), can be see as very compatible with the IOM approach to migration governance: The Global Forum on Migration and Development (GFMD) is a state-led, non-binding and informal process with a focus on «best practices» (Rother 2010). Starting out as a dialogue forum and trust-building exercise (Rother 2019), the process has gained prominence through the inclusion of migration in the Sustainable Development Goals (SDGs) (Piper 2017). IOM has played a very active role on the Government Meeting part of the GFMD, where it has provided background papers, provided speakers for roundtables on issues such as "Migration Profiles», "Comparing South-South mobility frameworks», "Empowerment of migrants by ensuring their health and wellbeing» and more. IOM has joined other organisations in programmes with a prominent place at the GFMD but by no means limited to it such as the joint IOM-UNDP Mainstreaming Migration into National Development Strategies programme since 2011 and the UN Joint Migration and Development Initiative. 9 As can be expected, the focus of all this input is on implementation of programs, mainstreaming, a "whole-of-government approach» and gathering data with little conceptualisation of a more comprehensive approach to development and root causes of underdevelopment. IOM also hosts the small permanent secretariat of the GFMD (which is to a large degree organised by changing host countries and support fora).

The IOM contributed in a similar way to the two UN-HLDs in 2006 and 2013

${ }^{9}$ https://weblog.iom.int/ensuring-migration-benefits-development 
and this involvement has led to a major role of the organisation in the deliberations on a Global Compact for safe, orderly and regular migration (the title being based on the SDG principles). The range of activities conducted by IOM can be seen as a clear indicator of the level of agency achieved by the organisation; it defines its role as "working to mobilize member states and engage diverse stakeholders to ensure that all voices are heard in setting the global migration agenda for years to come, and [...] providing its technical and policy expertise to support the GCM process, as called for in the modalities resolution» (International Organization for Migration 2017a). These activities encompass thematic papers, national consultations, civil society engagement (see below) RCPs, devoting the 2017 International Dialogues on Migration, its primary policy dialogue forum for Member and Observer States and partner organisationd to the Global Compact, the above-mentioned research leader syndicate and media outreach.

IOM has published a «vision» on the global compact on migration, where the rights of migrants have more prominence than in previous documents; for IOM,

The Global Compact presents an historical opportunity for achieving a world in which migrants move as a matter of choice rather than necessity, through safe, orderly and regular channels, and in which migration is well governed and able to act as a positive force for individuals, societies and States. IOM envisions a global compact that will place the rights, needs, capacities and contributions of migrants at its core, with a view to ensuring their safety, dignity and human rights (International Organization for Migration 2017b).

To realize this vision, IOM suggests to draw from three principles of the Migration Governance Framework, adopted by IOM Member States as a comprehensive framework for migration governance: adherence to international standards and the fulfilment of migrants' rights, evidence-based and whole-of-government approaches and fostering and relying on strong partnerships (idem).

Currently, IOM is carving out its role in the implementation of the GCM. It also has been assigned a critical role in the newly established UN Network on Migration: «IOM will serve as the Coordinator and Secretariat of all constituent parts of the Network $»^{10}$. The network is still in its early stages, but by not only

${ }^{10}$ http://www.migrationnetwork.un.org/sites/default/files/docs/UN _Network_on_Migration_ TOR.PDF 
providing the coordination (the organisations Director General or his designee) but also staffing the secretariat of the network (although the organisation «would also be open to secondments from UN system partners $\left.{ }^{11}\right)$, IOM clearly has a strong influence on the process. After the failure of the now obsolete Global Migration Group (GMG) to achieve coherent policies among its membership organisations, the network is now tasked with the goal to realize just that: "Support coherent action by the UN system at country, regional and global levels in support of GCM implementation, where such action would add value, while ensuring well-defined linkages with UN structures at all levels» (ibid.). The network has also established the Multi-Partner Trust Fund (MPTF) to fund collective action on implementing the GCM. While it might still be early to assess the prospects of the network, it can be said as an initial observation that the network has started to improve the communication of joint projects by its member. For example, a statement on Covid-19 issued on March 20, 2020, convened a fairly strong message against xenophobia under the heading "Covid-19 Does Not Discriminate; Nor Should Our Response $»^{12}$. This statement also found approval among various civil society representatives and activists during two «UN Network Listening Sessions with stakeholders on the Covid-19 crisis and migrants» held on April 1, 2020. These were organized by the Civil Society Liaison Officer of the network, Monami Maulik, a long-time migrant's rights activist, now also based at, though independent from, IOM. Nonetheless, these activities are in line with the increasing interaction between the organisation and migrant civil society.

\section{$I O M$ and migrant civil society}

While the IOM has been very prominent at the government part of the GFMD meetings, for several years it had a minor presence at the civil society days of the forum. This can be contributed to a wide-spread distrust among activists towards the organisation, which they consider an agent for neoliberal policies such as the commodification of labour, border management, deportations in the guise of voluntary returns and bad practices on the grounds such as the Australian detention camp ((criticism gathered at numerous civil society events; see also

${ }^{11}$ https://migrationnetwork.un.org/about\#

${ }^{12}$ https://migrationnetwork.un.org/statements/covid-19-does-not-discriminate-nor-should-our -response 
Rother 2013). In the 2016 GFMD in Bangladesh and the 2017 meeting in Berlin, Germany, IOM has been more involved in these civil society days, not the least as a resource person on the global compact. Civil society representatives have also put up challenges to IOM; in Berlin, there were calls to «think about a new $I O M »$ and advocacy to ask for a protection mandate of the organisation.

Still, it has become obvious that civil society is the next in the row of stakeholders IOM tries to reach out to. This can be seen in the increasing notion of human rights in the organisations documents and by the designation of Colin Rajah, a long-time activist for migrants' rights, as its civil society liaison focal point in order «to help facilitate the participation of civil society leaders during consultations for the Global Compact on Migration» ${ }^{13}$ Five informal interactive multi-stakeholder hearings, that were called for in the compact modalities were organized by IOM. These took place between October 2017 and July 2018 in Geneva and New York. The IOM civil society liaison officer described his role in the process as «to ensure that civil society could have the maximum possible engagement throughout negotiations» (Interview C. Rajah, March 4, 2019). Representatives of migrant rights umbrella organisations appreciated the funding and support by IOM, however remained cautious to not be co-opted: «we established a firewall between the compact side of IOM and its institutional and operational side» (Interview with activist, 5 March 2019) - meaning that civil society representatives were not influenced by the funding with regards to their critique of IOMs operations on the ground and on the regional level. Civil society organisations also organized their own consultative structures, build alliances with like-minded states and produced independent inputs for the Compact (Rother and Steinhilper 2019).

\section{Conclusion}

This paper has argued that an analysis of IOM as merely as service provider and tool of states' interests' runs the risk of missing out on several important aspects of the organisation. By using insights from International Relations and organisation theory, the multiple levels of IOM structure and engagement can be more

${ }^{13}$ https://www.iom.int/news/second-informal-thematic-consultation-global-compact-migration -focused-drivers-migration 
fully captured. It has been argued that IOM can certainly be considered an actor in global migration governance with a degree of independence that reaches beyond the principal-agent relationship. This has become particularly obvious in the organisation's role in the deliberations of the global compact, where IOM defined its role in mobilizing its member states and reaching out to multiple stakeholders.

This stakeholder-outreach has been instrumental in the increased agency of IOM in the past two decades, as has been the thematic expansion of the organisation to issues such as migration and development, climate migration and global migration governance more generally. It has to be seen, though, if this strategy ultimately will end up bringing the organisation more fully into the United Nations system - a suggestion that reaches back to the 2015 Global Commission on International Migration and plans to merge IOM and UNHCR into a World Organization for Refugees and Migrants (Baldwin-Edwards 2005; Global Commission on International Migration (GCIM) 2005). While IOM has certainly left its mark on the various global debates and processes, there are indicators that this is a two-way-process and further analysis should focus on how the organisation might be socialized by this interaction with a wider range of stakeholders and exposure to critical discourses.

\section{Acknowledgements}

The author is grateful to the Wissenschaftliche Gesellschaft at the University of Freiburg for supporting his participation in the 2020 GFMD in Quito, Ecuador.

\section{Bibliography}

Andrijasevic, Rutvica and William Walters (2010), «The International Organization for Migration and the International Government of Borders», Environ Plan D, 28(6), pp. 977-999. DOI: 10.1068/d1509.

Ashutosh, Ishan and Alison Mountz (2011), «Migration management for the benefit of whom? Interrogating the work of the International Organization for Migration», Citizenship Studies, 15(1), pp. 21-38. DOI: 10.1080/13621025.2011.534914. 
Baldwin-Edwards, Martin (2005), "Migration in the Middle East and Mediterranean», a paper prepared for the Policy Analysis and Research Programme of the Global Commission on International Migration (GCIM).

Barber, Pauline Gardiner and Catherine Bryan (2018), «International Organization for Migration in the field, wwalking the talk of global migration management in Manila», Journal of Ethnic and Migration Studies, 44(10), pp. 1725-1741. DOI: 10.1080/ 1369183X.2017.1354068.

Baum, Joel A. and Tim J. Rowley (2007), "Companion to organizations: an introduction", in Joel A.C. Baum (ed.), The Blackwell companion to organizations, Malden, Mass, Blackwell, pp. 1-34.

Betts, Alexander (ed.) (2011a), Global Migration Governance, Oxford, Oxford University Press.

(2011b), «Introduction: global migration governance, in Alexander Betts (ed.), Global Migration Governance, Oxford, Oxford University Press, pp. 1-33.

Bradley, Megan (2020), The international organization for migration. Challenges and complexities of a rising humanitarian actor, London, Routledge.

Brehm, John and Scott Gates (2002), Working, shirking and sabotage. Bureaucratic response to a democratic public, Ann Arbor, The University of Michigan.

Castles, Stephen and Raúl Delgado Wise (eds.) (2008), Migration and Development: Perspectives from the South. International Organization for Migration, Geneva, Organización Internacional para las Migraciones (OIM).

Centro de Información de las Naciones Unidas (UNIC) (s/f), «Managing Migration for the Benefit of All», Tehran, in http://www.unic-ir.org/Factsheets/Factsheet-Eng-IOM.pdf Cohen, Max and Saskia Llewellyn (2019), "The politics of migration data: putting the spotlight on the IOM», Routed. Migration \& Immobility Magazine, in https://es.routedmagazine.com/politics-of-migration-data

De Jong, Sara and Petra Dannecker (2017), «Managing Migration with Stories? The IOM ¿I am a migrant Campaign», Journal für Entwicklungspolitik, 33(1), pp. 75-101. DOI: 10.20446/JEP-2414-3197-33-1-75.

Deardorff Miller, Sarah (2017), UNHCR as a Surrogate State. Protracted Refugee Situations, New York, Routledge.

Delgado Wise, Raul (2018), «Is there a space for counterhegemonic participation? Civil society in the global governance of migration», Globalizations, 15(6), pp. 746-761. DOI: 10.1080/14747731.2018.1484204. 
Dini, Sabine (2018), «Migration management, capacity building and the sovereignty of an African State. International Organization for Migration in Djibouti», Journal of Ethnic and Migration Studies, 44(10), pp. 1691-1705. DOI: 10.1080/1369183X. 2017.1354058.

Ellis, David C. (2010), «The organizational turn in international organization theory, Journal of International Organizations Studies, 1(1), pp. 11-28.

Fine, Shoshana (2018), "Liaisons, labelling and laws. International Organization for Migration bordercratic interventions in Turkey», Journal of Ethnic and Migration Studies, 44(10), pp. 1743-1755. DOI: 10.1080/1369183X.2017.1354073.

Gammeltoft-Hansen, Thomas and Ninna Nyberg Sørensen (eds.) (2013), The migration industry and the commercialization of international migration, London/New York, Routledge.

Geiger, Martin (2018), «Ideal partnership or marriage of convenience? Canada's ambivalent relationship with the International Organization for Migration», Journal of Ethnic and Migration Studies, 44(10), pp. 1639-1655. DOI: 10.1080/1369183X.2017. 1354033.

Geiger, Martin and Antoine Pécoud (eds.) (2010), The politics of International Migration Management, London, Palgrave.

Georgi, Fabian (2019), Managing Migration? Eine kritische Geschichte der Internationalen Organisation für Migration (IOM), Berlin, Bertz+Fischer.

Global Commission on International Migration (GCIM) (2005), «Migration in an interconnected world: new directions for action", Report of the Global Commission on International Migration, Geneva.

Hawkins, Darren G., David A. Lake, Daniel L. Nielson and Michael J. Tierny (eds.) (2006), Delegation and agency in international organizations, Cambridge, Cambridge University Press.

Hooghe, Liesbet, Gary Marks, Tobias Lenz, Jeanine Bezuijen, Besir Ceka and Svet Derderyan (2017), Measuring international authority. A Postfunctionalist Theory of Governance, Oxford, Oxford University Press.

Kapur, Devesh (2003), Remittances: The New Development Mantra? Washington DC, The World Bank.

Korneev, Oleg (2018), "Self-legitimation through knowledge production partnerships. International Organization for Migration in Central Asia», Journal of Ethnic and Migration Studies, 44(10), pp. 1673-1690. DOI: 10.1080/1369183X.2017.1354057.

Lenz, Tobias (2017), "The Rising Authority of International Organisations», GIGA Focus (4), in https://www.giga-hamburg.de/en/publication/the-rising-authority-of -international-organisations 
McAuliffe, Marie and Michele Klein Solomon (2017a), «Introduction», in Marie McAuliffe and Michele Klein Solomon (eds.), Migration Research Leaders' Syndicate. Ideas to inform international cooperation on safe, orderly and regular migration, Geneva, OIM, pp. 1-5.

(2017b), Migration Research Leaders' Syndicate. Ideas to inform international cooperation on safe, orderly and regular migration, Geneva, OIM.

Oestreich, Joel E. (ed.) (2012a), International organizations as self-directed actors. A framework for analysis, London, Routledge.

(2012b), «Introduction», in Joel E. Oestreich (ed.), International organizations as self-directed actors. A framework for analysis, London, Routledge, pp. 1-25.

Organización Internacional para las Migraciones (OIM) (2015), «Migration in a world in disarray): IOM director general», in https://www.iom.int/news/migration -world-disarray-iom-director-general

(2017a), «Ensuring Migration Benefits Development», in https://weblog.iom. int/ensuring-migration-benefits-development

(2017b), IOM Activities in Support of the Global Compact for Migration, Geneva, OIM.

(2017c), IOM vision on the global compact on migration, Geneva, OIM.

(2017d), «Second informal thematic consultation for the global compact on migration focused on drivers of migration", in https:/www.iom.int/news/ second-informal-thematic-consultation-global-compact-migration-focused-driversmigration

Pécoud, Antoine (2015), Depoliticising Migration. Global Governance and International Migration Narratives, Basingstoke, Palgrave Pivot.

(2018), «What do we know about the International Organization for Migration?", Journal of Ethnic and Migration Studies, 44(10), pp. 1621-1638. DOI: 10.1080/1369183X.2017.1354028.

Piper, Nicola (2017), "Migration and the SDGs», Global Social Policy (40), DOI: 10.1177/1468018117703443.

Piper, Nicola and Stefan Rother (2012), «Let's argue about migration: advancing a right(s) discourse via communicative opportunities», Third World Quarterly, 33(9), pp. 17351750. DOI: $10.1080 / 01436597.2012 .721271$.

(2014), «More than remittances: resisting the dominant discourse and policy prescriptions of the global «Migration-Development-Mantra», Journal für Entwicklungspolitik (JEP), 30(1), pp. 44-66.

Potaux, Claure (2011), «The current role of the International Organization for Migration in developing and implementing migration and mobility partnerships, in Rahel Kunz, 
Sandra Lavenex and Marion Panizzon (eds.), Multilavered Migration Governance. The promise of partnership. Milton Park, Abingdon, Oxon, England, New York, Routledge, pp. 183-204.

Proceso de Bali (2018), "About the Bali Process», in https://www.baliprocess.net/

Red de las Naciones Unidas sobre Migración (s/f), «About us», in http://www.migrationnetwork.un.org/sites/default/files/docs/un_Network_on_Migration_TOR.PDF (20 de marzo de 2020), "COVID-19 does not discriminate; nor should our response», in https://migrationnetwork.un.org/statements/covid-19-does-not -discriminate-nor-should-our-response

Rother, Stefan (2010), «The GFMD from Manila to Athens: one step forward, one step back?, Asian and Pacific Migration Journal, 19(1), pp. 157-173.

(2013), "A tale of two tactics: civil society and competing visions of global migration governance from below», in Martin Geiger and Antoine Pécoud (eds.), Disciplining the Transnational Mobility of People, Palgrave Macmillan, pp. 41-62.

(2018), «The ASEAN forum on migrant labour: a space for civil society in migration governance at the regional level?», Asia Pacific Viewpoint, 59(1), pp. 107-118. (2019), «The Global Forum on Migration and Development (GFMD) as a venue of state socialization: a stepping stone for multi-level migration governance?», Journal of Ethnic and Migration Studies, 45(8), pp. 1258-1274. DOI: 10.1080/136918 3X. 2018.1441605. Rother, Stefan and Elias Steinhilper (2019), «Tokens or stakeholders in global migration governance? The role of affected communities and civil society in the global compacts on migration and refugees», International Migration, 57(6), pp. 243-257. DOI: 10.1111/ imig.12646.

Scheel, Stephan and Funda Ustek-Spilda (2019), "The politics of expertise and ignorance in the field of migration management», Environ Plan D, 37(4), pp. 663-681. DOI: 10.1177/ 0263775819843677.

United Nations General Assembly (2016), «New York declaration for refugees and migrants», International Journal of Refugee Law, 28(4), pp. 704-732. DOI: 10.1093/ijrl/eew057

Waltz, Kenneth Neal (2001), Man, the state, and war. A theoretical analysis, New York, Columbia University Press.

Weiss, Thomas G. and Nicholas R. Micinski (2016), International Organization for Migration and the un System: a missed opportunity. Future United Nations Development System. New York.

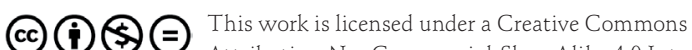
Attribution-NonCommercial-ShareAlike 4.0 International License 